\title{
DATING ORGANIC TEMPER OF CERAMICS BY AMS: SAMPLE PREPARATION AND CARBON EVALUATION
}

\section{Denise C Gomes}

Museu de Arqueologia e Etnologia-USP, Avenida Prof. Almeida Prado, 1466, Cidade Universitária, São Paulo 05508-900, Brazil. Email: denisecavalcante@yahoo.com

\section{Oscar Vega}

Instituto de Pesquisas Energéticas e Nucleares-USP, Travessa R, 400, Cidade Universitária, São Paulo 05508-900, Brazil. Email: ovega@net.ipen.br

ABSTRACT. We describe a new methodology for separating organic temper from archaeological ceramics from Brazilian Amazonia. These experimental procedures were designed to directly date ceramic samples by accelerator mass spectrometry (AMS). An evaluation of the total carbon indicates the samples' potential for dating.

\section{INTRODUCTION}

Since the 1980s, accelerator mass spectrometry (AMS) has made it possible to date organics using smaller samples than those necessary for conventional radiocarbon dating. However, AMS encounters problems in dating archaeological ceramics because of the different origins of carbon present in pottery. These sources of carbon include the carbon in clays, as well as carbon contributed by temper, fuel, food remains, and geochemical contamination, any of which may affect ${ }^{14} \mathrm{C}$ dates (Gabasio et al. 1986; Evin et al. 1989; Johnson et al. 1988; Hedges et al. 1992).

Among these sources of carbon, clays are especially significant, for most of them are said to contain amounts of carbon of diverse "geological" ages (Gabasio et al. 1986; Johnson et al. 1988), which can influence the results of dating, sometimes increasing the apparent age of the potsherd. Depending on the firing temperature $\left(600-900^{\circ} \mathrm{C}\right)$ this carbon may or may not be oxidized (Johnson et al. 1986). In order to avoid invariable contamination by the detrital carbon from the clay and to ensure the real source of carbon to be dated, the organic temper, when available, should be extracted from the clay matrix.

Hedges et al. (1992), discussing the possibility of dating selected pottery fractions by the AMS method, have noted the importance of using organic temper removed from the sherds as a reliable dating material. Although they describe painstaking methods of microscopic excavation of sherds, the separation process presented here, for 2 different kinds of organic temper, can be considered low-cost and relatively fast.

\section{METHODS}

\section{The Separation Process}

In archaeological sites in lowland South America, especially in Amazonia, 2 kinds of organic temper are conspicuous in ceramics: spicules of freshwater sponges (cauixi) of different species rich in silica (Bergquist 1978), and bark ashes (cariapé) also containing silica (Linné 1932; Rye 1981; Shepard 1985). In this experiment, the sherds tempered with sponge spicules came from Santarém region, in the state of Pará. They belong to a museum collection, without contextual information. Only for the 4th sample, tempered with bark ashes, do we have the precise geographic location: site Marabitana II, Vaupés river $\left(00^{\circ} 26^{\prime} 00^{\prime \prime} \mathrm{N}, 68^{\circ} 50^{\prime} 05^{\prime \prime} \mathrm{W}\right)$.

Almost 40 years ago, Evans and Meggers (1962, p 244) described a pioneering experiment in ${ }^{14} \mathrm{C}$ dating using these same organic tempers: “... the sherds were broken by mallet into fragments, and 
further reduced in size with mortar and pestle to facilitate filtration and rinsing during and after hydrochloric acid treatment for removal of inorganic carbon compounds. The residue was then burned and $\mathrm{CO}_{2}$ collected and purified in the usual way."

In our experiment, different procedures were adopted for each of these elements, this time in order to prepare samples for AMS dating. Ceramic sherds weighing from 20 to $30 \mathrm{~g}$, tempered with sponge spicules, were powdered with a mortar and pestle (Figure 1). The material was sieved with 2 sieves of different sizes, the first one with 100 mesh and the second with 200 mesh. The sample obtained was successively washed with distilled water, then dried on a $250 \mathrm{~W}$ infrared lamp.

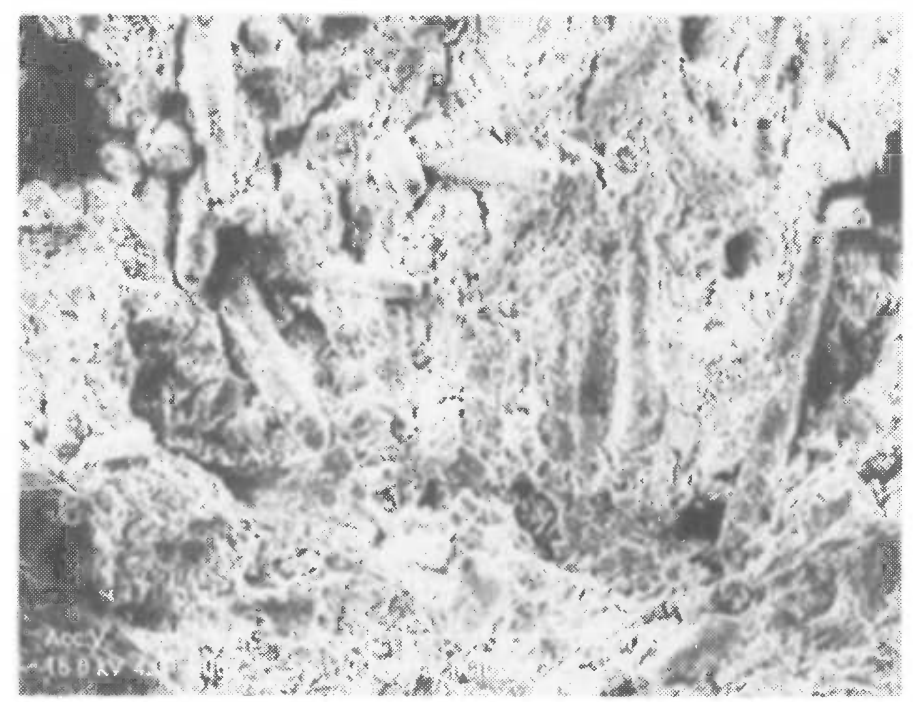

Figure 1 Sample 2 (clay matrix) showing the spicules of freshwater sponges. Legend:
ACC.V
Spot Magn
Det WD
$15.0 \mathrm{kV}$
4. $0200 \mathrm{x}$
SE 9.7 clay matrix

Because of the biological characteristics and morphology of the sponge spicules, the sample was tentatively passed through a Frantz magnetic separator (model L1, 115 volts) at $1.5 \mathrm{~A}$ and a lateral angle of 10 degrees. The process was repeated 2 times and resulted in 2 samples: nonmagnetic and magnetic. A high concentration of spicules $300-400 \mu \mathrm{m}$ long and $40 \mu \mathrm{m}$ wide (Volkmer-Ribeiro and Costa 1992) was found in the nonmagnetic sample (Figure 2), while the magnetic one presented sparse quantities of spicules and a more generalized mineral composition (Figure 3). Owing to other elements still present in the nonmagnetic sample (quartz, humic substances, and bits of clay) pretreatment is required.

For the second organic temper, bark ashes, the process adopted was similar to the 1st experiment. The sherds were powdered with a mortar and a pestle, but in a very coarse granularity, in order to preserve the grains of temper as much as possible. As in the first case, the sample was sieved with 2 sieves, the first with 100 mesh and the second with 200 mesh. The content was washed several times with distilled water only.

The sample was filtered through $3 \mu \mathrm{m}$ pore diameter qualitative analysis paper, then dried under a $250 \mathrm{~W}$ infrared lamp. The last step was separating the large grains of temper $(0.5-2 \mathrm{~mm})$ mixed in the powdered clay, using metallic tweezers. Since the light-gray-colored grains of bark ashes were preserved, their visual recognition was possible (Figure 4). 


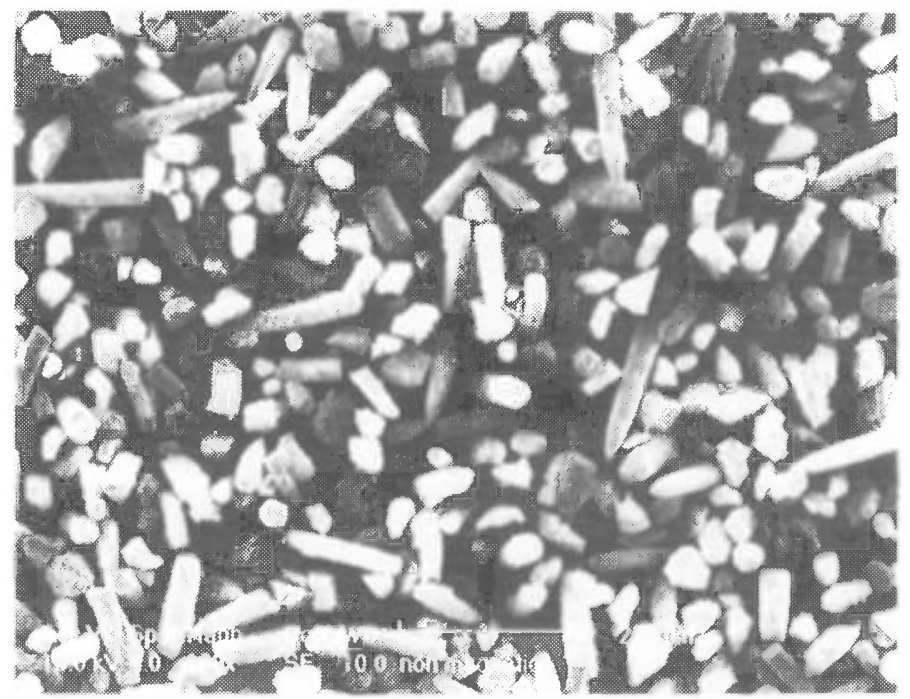

Figure 2 Sample 2 (nonmagnetic): concentration of spicules; some of them were broken during the separation process. Legend:

$$
\begin{array}{lllrl}
\text { ACC.V } & \text { Spot } & \text { Magn } & \text { Det } & \text { WD } \\
5.0 \mathrm{kV} & 4.0 & 100 \mathrm{x} & \text { SE } & 10.0 \text { nonmagnetic }
\end{array}
$$

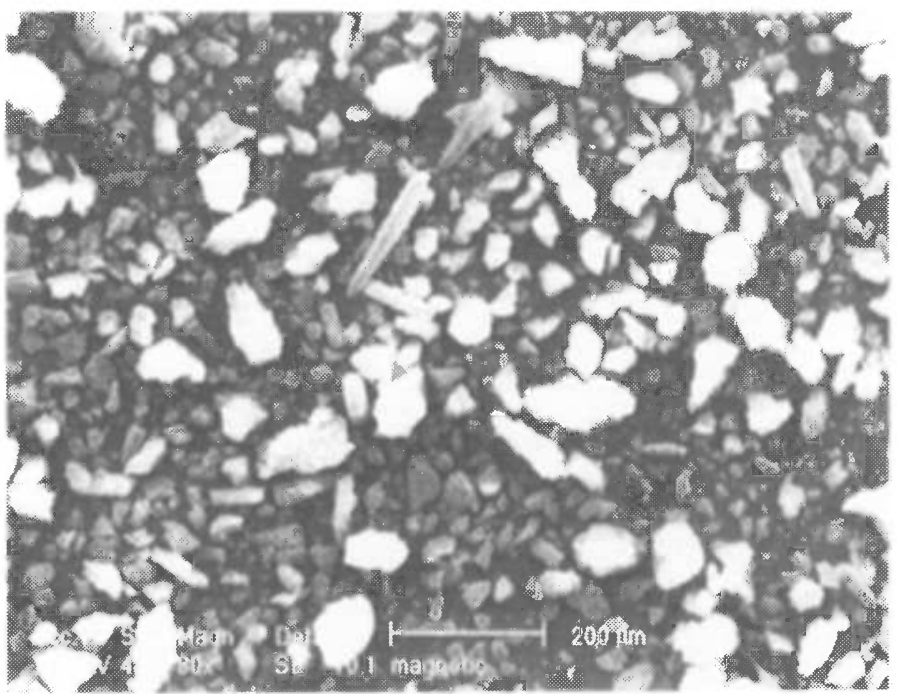

Figure 3 Sample 2 (magnetic): sparse quantities of spicules, bits of clay and quartz. Legend:

$$
\begin{array}{lllrl}
\text { ACC.V } & \text { Spot } & \text { Magn } & \text { Det } & \text { WD } \\
5.0 \mathrm{kV} & 4.0 & 80 \mathrm{x} & \text { SE } & 10.1 \text { magnetic }
\end{array}
$$

\section{Analytical Equipment and Methodology}

The carbon analyses were done using an absorption infrared analyzer, model CS-400, made by Laboratory Equipment Company (LECO). The process was begun by weighing the sample out into a ceramic crucible using an electronic balance. After the addition of an accelerator material, the sam- 


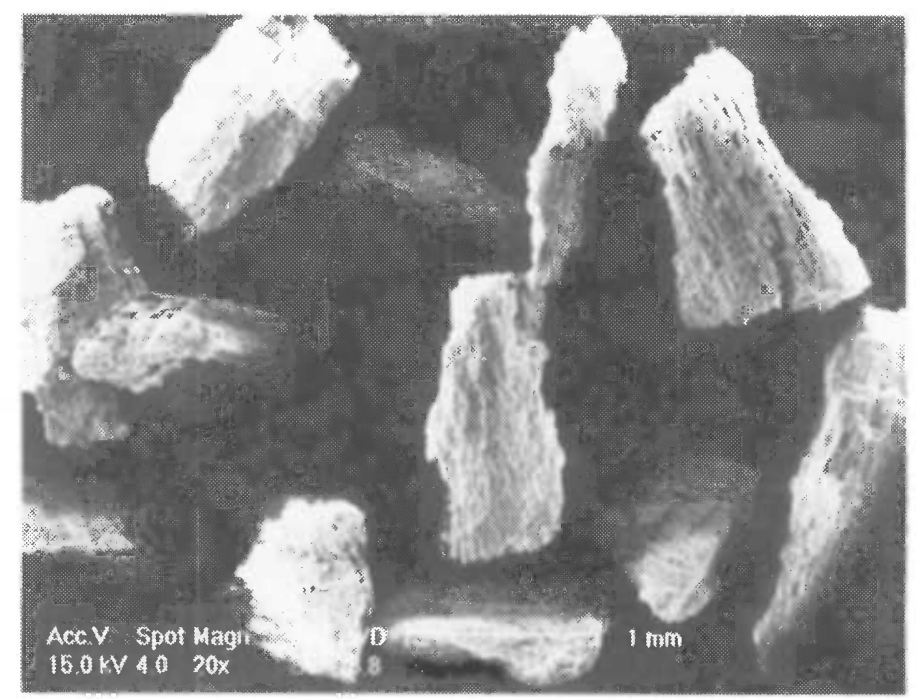

Figure 4 Sample 4: grains of bark ashes. Legend:

$$
\begin{array}{lllllll}
\text { AcC. V } & \text { Spot } & \text { Magn } & \text { Det } & \text { WD } & & \\
15.0 \mathrm{kV} & 4.0 & 20 \mathrm{x} & \mathrm{SE} & 8.8 & \text { bark ashes }
\end{array}
$$

ple crucible was placed in a high-frequency furnace, where sample combustion takes place in an oxidizing atmosphere. During combustion all elements of the sample oxidize. Carbon-bearing elements are reduced releasing the carbon, which immediately binds with the oxygen to form $\mathrm{CO}$ and $\mathrm{CO}_{2}$.

Subsequently, sample gases are swept into the carrier steam. $\mathrm{CO}$ is converted to $\mathrm{CO}_{2}$ in the catalytic heater assembly. Carbon is measured as $\mathrm{CO}_{2}$ in the infrared cell as gases flow through it. The total carbon, as $\mathrm{CO}_{2}$, is detected on a continuous and simultaneous basis. The cell consists of an infrared source, a chopper motor, a narrow bandpass filter, a condensing cone, an infrared energy detector, and the cell body.

Radiation energy is chopped at a rate of $87.5 \mathrm{~Hz}$ before it enters the cell body. The chopped energy enters the cell body through a window, travels through the cell body, then exits through a second window and a precise wavelength filter. The selective filter passes only the $\mathrm{CO}_{2}$ absorption wavelength into a condensing cone that concentrates the energy at the detector. The solid-state detector is AC-coupled to a preamplifier. As the gas concentration increases the voltage to the preamplifier decreases.

\section{RESULTS AND DISCUSSION}

The ceramic samples tempered with sponge spicules were classified as magnetic or nonmagnetic, according to the process of separation described above. The mass used for each analysis was around $100 \mathrm{mg}$. Three to five parts of the original samples were analyzed to determine reproducibility.

The results (Table 1) indicate that the nonmagnetic samples, which contain the higher concentration of sponge spicules and therefore potentially of organic material to be dated, have the lower amount of carbon. Sample 3 was $30 \%$ reduced in carbon compared to its magnetic counterpart. This confirms a pattern already inferred by Evans and Meggers (1962), who reported $7{ }^{14} \mathrm{C}$ dates for lowland South America ceramic samples with organic temper (charcoal, cariapé, and cauixi), with carbon percentages ranging from $0.3 \%$ to $1.8 \%$. 
Table 1 Carbon analyses of archaeological ceramics from Amazonia

\begin{tabular}{|c|c|c|}
\hline Sample nr & Sample description & $\begin{array}{c}\text { Total carbon } \\
(\%)^{\mathrm{a}}\end{array}$ \\
\hline 1 & $\begin{array}{l}\text { Sponge spicules/nonmagnetic: } \\
\text { Metania reticulata }{ }^{\mathrm{b}} \\
\text { Drulia uruguayensis } \\
\text { Trochospongilla paulula } \\
\text { Trochospongilla pensylvania }\end{array}$ & 0.20 \\
\hline $\begin{array}{l}1 \mathrm{a} \\
2\end{array}$ & $\begin{array}{l}\text { Sponge spicules/magnetic } \\
\text { Sponge spicules/nonmagnetic } \\
\text { Metania reticulata } \\
\text { Drulia uruguayensis } \\
\text { Oncosclera navicella }\end{array}$ & $\begin{array}{l}0.56 \\
0.27\end{array}$ \\
\hline $2 \mathrm{a}$ & Sponge spicules/magnetic & 0.54 \\
\hline 3 & $\begin{array}{l}\text { Sponge spicules/nonmagnetic } \\
\text { Metania reticulata } \\
\text { Drulia uruguayensis } \\
\text { Radiospongilla amazonensis } \\
\text { Corvospongilla seckti } \\
\text { Oncosclera petricola }\end{array}$ & 0.09 \\
\hline $3 a$ & Sponge spicules/magnetic & 0.30 \\
\hline 4 & Bark ashes & 0.25 \\
\hline
\end{tabular}

They discarded 2 dates, explaining the erroneous results as a consequence of the samples' small percentage of carbon, $0.3 \%$ and $0.6 \%$, respectively. The authors also suggested the sponge spicules' deficiency in ${ }^{14} \mathrm{C}$ as a reason for these results. Although Junk and Furch (1985) registered a deficiency in carbonates (and probably in ${ }^{14} \mathrm{C}$ ) in waters of the lower and middle Amazon and its tributaries of clear waters (Tapajós) and dark waters (Negro), Evans and Meggers' statement cannot be generalized. Moreover, we have to take in consideration the natural deficiency in organic matter of some species of freshwater sponges, whose preferred habitat is in the rocky bottoms of Amazonian rivers (Volkmer-Ribeiro and Tavares 1993; Tavares and Volkmer-Ribeiro 1997). These sponges are remarkable for their large spicules, rich in silica, and their reduced amount of spongine (organic matter) binding the spicules. Two examples are the species Drulia uruguaiensis and Oncosclera navicella. On the other hand, the same characteristics can be found in Metania reticulata, a species of floodwater habitats (Volkmer-Ribeiro, personal communication 1999).

However, the remaining 5 dates were all acceptable for the authors, including even 1 date obtained from a sample with $0.6 \%$ of carbon. Comparing our results to Evans and Meggers', only sample number 3 seems to be problematic. We observed the reduction of carbon in nonmagnetic relative to magnetic samples in samples 2 and 2a: the former contained only $50 \%$ as much carbon as the latter. Sample number 4 , bark ashes, also indicates potential for dating, comparable to the nonmagnetic sponge spicule samples.

In their field and laboratory experiments, Evin et al. observed that in oxidizing conditions "the carbon from the temper disappears almost completely whatever the temper material. Only very little 
remained" (1989, p 279). Nevertheless, when present in sufficient amounts and extracted from the sherds, organic temper seems to be a reliable source for AMS dating (Hedges et al. 1992).

\section{CONCLUSION}

Further dating of these samples will test the hypotheses presented here. Pretreatment is still necessary to eliminate inorganic carbon, especially in the sponge spicule samples. The choice of ceramic samples tempered with sponge spicules belonging to Metania reticulata, Drulia uruguaiensis, and Oncosclera navicella will help verify Evans and Meggers' conclusion about the deficiency of ${ }^{14} \mathrm{C}$ in these species. Finally, we believe that the process of separation of the organic temper from ceramics can isolate fractions that correspond to culturally introduced carbon, contributing to the potential of AMS as a technique for directly dating archaeological artefacts.

\section{ACKNOWLEDGMENTS}

The first author is indebted to Dr Koji Kawashita, Geochronological Research Center of the Geoscience Institute-USP, Brazil, for supervising the separation process of organic ceramic temper. She also would like to express her gratitude to Vasco Antônio P. Loios, technician of the Geochronology Separation Laboratory, Geoscience Institute-USP, Brazil, for his support. Special thanks are due to Dr Cecília Volkmer-Ribeiro, from the Museu de Ciências Naturais do Rio Grande do Sul, Brazil, for the zoological analysis of the freshwater sponges contained in the ceramics. Finally, this manuscript benefits from the comments and encouragement of Eduardo Góes Neves, from MAE-USP, and the reviewers from Radiocarbon.

\section{REFERENCES}

Bergquist P. 1978. Sponges. Berkeley and Los Angeles: University of California Press. 268 p.

Evans C, Meggers B. 1962 Use of organic temper for carbon 14 dating in Lowland South America. American Antiquity 28(2):243-5.

Evin J, Gabasio M, Lefevre JC. 1989. Preparation techniques for radiocarbon dating of potsherds. Radiocarbon 31(3):276-83.

Gabasio M, Evin J, Arnal GB, Andrieux P. 1986. Origins of carbon in potsherds. Radiocarbon 28(2A):711-8.

Hedges REM, Tiemei C, Housley RA. 1992. Results and methods in the radiocarbon dating of pottery. Radiocarbon 34(3): 906-15.

Johnson JS, Clark J, Miller-Antonio S, Robins D, Schiffer MB, Skibo JM. 1988. Effects of firing temperature on the fate of naturally occurring organic matter in clays. Journal of Archaeological Science 15: 403-14.

Junk WJ, Furch K. 1985. The physical and chemical properties of Amazonian waters and their relationships with the Biota. In: Prance GT, Lovejoy TE, editors. Amazonia. London: Pergamon. p 3-17.
Linné S. 1932. Contribution a l'étude de la ceramique sudamericaine. Revista del Instituto de Etnologia 7:199_ 232

Rye OS. 1981. Pottery Technology: Principles and Reconstruction. Washington (DC): Taraxacum. 150 p.

Shepard AO. 1985 Ceramics for the Archaeologist. 12th ed. Washington (DC): Carnegie Institution of Washington. $414 \mathrm{p}$.

Tavares MC, Volkmer-Ribeiro C. 1997. Redescrição das esponjas de água doce Oncosclera navicella (Carter,1881) (Potamolepidae) e Spongilla spoliata Volkmer-Ribeiro \& Maciel, 1883 (Spongillidae). Biociências 5:97-111.

Volkmer-Ribeiro C, Costa PR. 1992. On Metania spinata (Carter, 1881) and Metania kiliani n. sp.: Porifera, Metaniidae Volkmer-Ribeiro, 1986. Amazoniana 13(1):7-16.

Volkmer-Ribeiro C, Tavares MC. 1993. Sponges from the flooded sandy beaches of two Amazonian clear water rivers (Porifera). Iheringia, Séries Zoologia (Porto Alegre) 75:187-8. 